INSIGHTS INTO REGIONAL DEVELOPMENT

ISSN 2669-0195 (online) http://jssidoi.org/IRD/

2021 Volume 3 Number 1 (March)

http://doi.org/10.9770/IRD.2021.3.1(3)

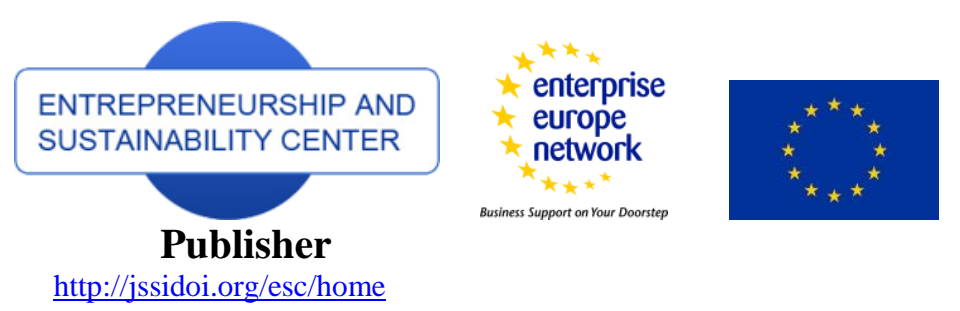

\title{
INTERNATIONALIZATION IMPACTS ON TEAM INNOVATION IN LITHUANIAN HIGH-TECH FIRMS
}

\author{
Mindaugas Laužikas ${ }^{1}$, Aistė Miliūtė ${ }^{2}$, Mukhammad Khalili ${ }^{3}$ \\ ${ }^{1}$ Global Innovation Learning Ecosystem (GILE) Experts, Corradino Industrial Estate, Paola, Malta \\ 2JSC AKVAVITA, Neravu st. 100, Viečiünai, Lithuania \\ 1,2,3 Vilnius University Business School, Saulètekio Av. 22, LT-10225 Vilnius, Lithuania \\ E-mails:ㅍmindaugas.lauzikas@gmail.com; ${ }^{2}$ aiste_miliute@yahoo.com $;{ }^{3}$ m.louie.khalili@gmail.com
}

Received 15 October 2020; accepted 10 January 2021, published 30 March 2021

\begin{abstract}
Given a well-established literature on internationalization processes and its main impacts on companies' performance (Begeny, 2018; Bužavaite et al., 2019), it is worth examining how internationalization affects companies, driven by innovation at three different levels (individual, team and organizational) which is anchored in three main pillars: effectiveness, creativity and efficiency. The first pillar is related to strategic decision-making and business intelligence (along with data collection and analysis; setting efficiency criteria, strategic goals and outputs, as well as the tactics for each criteria). The second pillar covers a set of internationalization-related aspects, such as creative ideas generation, marketing and communications strategies, HR and R\&D culture, leadership and talent development; while the third pillar is liaised with monitoring and execution of innovative activities. In line with studies with regard to innovation processes (Szopik-Depczyńska, 2015; Gries et al., 2017; Von Schomberg and Blok, 2018), the present paper continues examining the innovation performance; however, the main focus is on team innovation performance or the ways of unlocking the internationalization potential within team innovation processes via a set of aspects, such as effective decision-making, creative and divergent thinking, and efficient execution in teams. In light of the emergence of modern technology, employees of Lithuanian high-tech companies were selected for a quantitative survey, while scrutinizing the liaison between team internationalization and innovation commercialization success. Having the primary quantitative data (related to internationalization level, creative thinking, innovation performance in high-tech respondents' teams) collected and analysed, further on, the innovation performance improvement suggestions are provided for the leaders of high-tech international teams.
\end{abstract}

Keywords: internationalization; technologies; impacts; team innovation; high-tech; commercialization; creativity; effectiveness; efficiency

Reference to this article should be made as follows: Laužikas, M., Miliūtè, A., Khalili, M. 2021. Internationalization impacts on team innovation in Lithuanian high-tech firms. Insights into Regional Development, 3(1), 41-64. https://doi.org/10.9770/IRD.2021.3.1(3)

JEL Classifications: M130 
INSIGHTS INTO REGIONAL DEVELOPMENT

ISSN 2669-0195 (online) http://jssidoi.org/jesi/

2021 Volume 3 Number 1 (March)

http://doi.org/10.9770/IRD.2021.3.1(3)

Make your research more visible, join the Twitter account of INSIGHTS INTO REGIONAL DEVELOPMENT:

@IntoInsights

\section{Introduction}

The process of internationalization has become a key research axis among various scholars during the past few decades, especially since companies have been forced to compete not only in highly competitive domestic markets, but also in foreign regions. Driven by the globalization trends that continuously reshape the competition rules and international trade agreements, various economies tend to reduce the import barriers in both the developed and developing regions (Šumakaris \& Korsakienè, 2017), while innovation and creativity at individual, team and organizational levels emerge as a main driver for organizational change and a key success factor in terms of improved competitive advantages of a firm.

Thus, the research practices in the area of internationalization are gaining its momentum in educational and professional environments. Although this notion is commonly used in literature, it is considered to be multifaceted and holistic (Andersen, 1997). According to some scholars, internationalization first of all is related to the sequential and systematic participation in international activities and operations (Bilkey \& Tesar, 1977). Others argue that the internationalization process as a whole is the investment in international markets (Coviello \& McAuley, 1999). In addition to these two interpretations, the process of internationalization might be interpreted from the perspective of interactions, relationships and networks of organizations within a company and outside a firm (Johanson \& Mattsson, 1988). All the above interpretations were integrated into a more holistic approach to the internationalization process by Beamish (1990, p. 77p), linking it to "the process by which firms both increase their awareness of the direct and indirect influence of international transactions on their future, and establish and conduct transactions with other countries".

Over the past years, the traditional approach of Uppsala model was challenged by companies that were globally active from the beginning of their creation (Coviello and Munro, 1997). For instance, the international expansion of new technology-based firms showed an internationalization pattern when these entities were dependent on international agreements and attempted not to follow the gradual pattern of the Uppsala model. These companies were called 'Born-Global' by Rennie (1993), who represented a brand-new challenge for the internationalization of companies across the globe. The emerging multinational companies (meta-nationals) overcame their competitors by sensing, mobilizing and integrating their resources at the international level (Doz et al. 2001). Over the past decade, researchers in the field of international business have mainly used two theoretical frameworks to explain the internationalization of companies (Vissak \& Francioni, 2013): the 'Uppsala' model (Johanson \& Vahlne 2009) and the 'Born-Global' approach (Oviatt \& McDougall, 2005a). Moreover, the process of internationalization has been frequently discussed in terms of globalization (Begeny, 2018), where the process of internationalization was considered to be a response to globalization. This can be observed on a corporate level, where companies are finally starting sharing knowledge, technologies, values and ideas on a global scale (Bužavaite et al., 2019), where innovation brings various international stakeholders together in order to share resources and create a larger social value-added to the society.

The process of internationalization has been explained within many models and stages in the past few decades; however, three main models (the behavioural perspective of the Stages Models, the relationship approach of the Network Model, and the Foreign Direct Investment Model) are thought to be the traditional pathways to internationalization (Saarenketo et al. 2004). This is in line with the interpretation revealed five years prior to that, where one theoretical framework to explain the concept of internationalization was considered to be insufficient (Coviello and McAuley, 1999). On the contrary, Loane, McNaughton, \& Bell (2004) recognized the influence of multiple factors affecting the internationalization of smaller firms. 


\section{INSIGHTS INTO REGIONAL DEVELOPMENT}

ISSN 2669-0195 (online) http://jssidoi.org/jesi/

2021 Volume 3 Number 1 (March)

http://doi.org/10.9770/IRD.2021.3.1(3)

Make your research more visible, join the Twitter account of INSIGHTS INTO REGIONAL DEVELOPMENT:

@IntoInsights

There are basically two-stage models of internationalization according to contemporary literature (Moen \& Servais, 2002). The first one is the innovation-related model (Bilkey \& Tesar, 1977), which indicates that internationalization can be achieved through the management of the continuous learning process (Moen \& Servais, 2002), although the process can be jeopardized by weaker manager's skills and their adverse approach to risk. The second one is a the well-known 'Uppsala' model, which is more widely used to describe the process of internationalization: companies focus on the acquisition, integration, and gradual adoption of the international market knowledge (Chetty \& Campbell-Hunt, 2004), although the opponents argue that these two-stages models do not provide a sufficient explanation with regard to how and why the process of internationalization takes place (Andersen, 1993). Furthermore, these models do not help track company's progress throughout various stages. Thus, the Network Model was used as an alternative to explain a specific internationalization experience of companies that went through unique expansion pathways (Benito \& Welch, 1994). Based on this model, companies intend to enhance their position in international networks via various types of expenditures and collaboration strategies (Coviello \& McAuley, 1999). Within such networks, both inter-personal and interorganizational relationships can be developed among companies and employees respectively. This can be achieved on a formal and informal level, and could involve customers, suppliers, competitors, private and public support agencies as well as friends and family members (Coviello, 2006). As a result, such relationships could drive and facilitate company's internationalization process, but they could also hinder it (Coviello \& McAuley, 1999). Furthermore, the development of such networks might affect both the selection and the entry modes to international markets (Coviello \& Munro, 1997). However, Coviello and McAuley still recommend combining this approach with the Stages Models in order to be able to explain the internationalization among smaller companies (1999).

Contrary to the Stages Model and the Network Model, the Foreign Direct Investment (FDI) model is not used to explain the internationalization of small companies (Coviello \& McAuley, 1999). This model is instead being used to analyse the expansion of multinational corporations through three main streams: the ownership advantage, location advantage and internalization (Kumar \& Subramanian, 1997). Multinational corporations own rentyielding assets on a global scale, this grants them a substantial competitive advantage over their competitors in home and foreign markets alike. These corporations are also aware of the best entry modes for each foreign market by knowing its locational characteristics. Finally, thanks to the size of multinational corporations and the vast resources that they possess, business activities can be carried out by such organizations themselves (internalization), instead of outsourcing these activities to the third-party companies in order to reduce further corporate expenses. Some researchers (Morgan and Katsikeas, 1997) criticized the FDI model by claiming that it is not merely explaining a pattern of investment, while others consider FDI to be a managerial decision-making guideline (Coviello \& McAuley, 1999). In conclusion, even though the above-mentioned traditional internationalization models may have some common points, they definitely have diverse visions and perspectives, while innovation might require a prompt revision of these models, along with reshaped strategies and tactics behind.

\section{The Effects of Cultural Diversity on Team Innovation}

In addition to the expansion and growth-related aspects of internationalization, the cultural diversity of human resources (for example, the number of employees of foreign origin, country specialists, employees with international education background or the number of languages a team can cover) becomes an important factor for innovation-driven businesses. According to Cox and Blake (1991), having a workforce with a diverse cultural background can benefit companies with several competitive advantages, such as the increase in flexibility, creativity, and problem solving: these advantages can give companies a valuable edge over their competitors by 


\section{INSIGHTS INTO REGIONAL DEVELOPMENT}

ISSN 2669-0195 (online) http://jssidoi.org/jesi/

2021 Volume 3 Number 1 (March)

http://doi.org/10.9770/IRD.2021.3.1(3)

Make your research more visible, join the Twitter account of INSIGHTS INTO REGIONAL DEVELOPMENT:

@IntoInsights

improving the acquisition of resources or reducing the cost base. Moreover, Payne discussed the positive impacts of the diversity on the team creativity and innovation (1990). On the other hand, Priem demonstrated that the team diversity can also have negative effects on essential processes such as strategic decision-making, due to the incapability to identify the main strategic direction and back the strategic focus with various business intelligence techniques (1990). This can be observed in teams with a diverse cultural background; where employees may have different habits, beliefs and traditions; where companies struggle in implementing a geocentric philosophy or lack competences and expertise of applying a holistic human resource management style in practice. Even though creating a diverse team might seem to be an effective human resource strategy in theory (Cox \& Blake, 1991), bringing a diverse group of individuals to work together might trigger challenges and sometimes result in rather a fragmented and inefficient performance, if a creative and inspiring leadership is missing.

Another important internationalization aspect, which derives from the category of cultural diversity, is the lingual diversity of employees. Languages are communication media that possess a distinct ability to not only transform cultural and personal identities but also integrate them into a cultural group (Gollnick \&Chinn, 2006). A company is said to be lingually diverse when its employees have different language backgrounds, which might lead to the linguistic clusters (Welch and Welch, 1997). This can usually be observed in companies where employees from the mother company are sent to work to another country: they need to work with local people of the foreign branch; thus, the communication efficiency might be in danger. When one group of employees struggle in terms of languages, the whole communication system might be jeopardised (Lopéz-Duarte, Vidal-Suárez, 2010). A similar consequence can be triggered by the use of professional jargon among some team members, communication may be impeded and a smooth exchange of ideas is endangered (Maznevski, 1994).

The third aspect of internationalization in a company is the presence of employees with international educational backgrounds. This might seem insignificant to some employers, but the diversity in terms of educational background among employees increases the knowledge base and the creative potential of the company (Østergaarda, et al., 2011). As a matter of fact, educational backgrounds tend to facilitate the exploratory competence of a company through both better problem solving and generation of new ideas (Quintana-Garca and Benavides-Velasco, 2008). Employees that have studied in international educational institutions are more likely to provide creative and innovative ideas. This is simply due to the fact that such employees had more interaction with different cultures and types of individuals abroad, helping them to think outside the box by reflecting on the knowledge and experience they gained abroad.

It was discovered that the cultural diversity leads to the development of a strategy, which contributes to a bigger economic and social value-added (Payne, 1990). Therefore, employees with a high level of international education are needed in companies that attempt to pursue rapid internationalization via higher productivity, creativity, and efficiency (Onkelinx et al., 2016).

Another important internationalization aspect is related to the knowledge of the client base, because in today's international environments, driven by modern technology, companies can acquire and absorb the market knowledge more easily (Hislop, 2002). In reference to the Network Model, the degree of interorganizational and interpersonal relationships within the network of a company has a substantial impact on the internationalization success (Axelsson/ Easton 1992). These relationships usually involve clients, suppliers and competitors, that can encompass both the business and the social aspect of organizational boundaries. Bell adds that interfirm relationships can influence the efficiency of high-tech companies (1995). This was supported by other researchers, indicating that $34 \%$ of SMEs used cooperative relationships at some point in their internationalization process (O'Farrell et al. 1998). 


\section{INSIGHTS INTO REGIONAL DEVELOPMENT}

ISSN 2669-0195 (online) http://jssidoi.org/jesi/

2021 Volume 3 Number 1 (March)

http://doi.org/10.9770/IRD.2021.3.1(3)

Make your research more visible, join the Twitter account of INSIGHTS INTO REGIONAL DEVELOPMENT:

@IntoInsights

In line with the already discussed internationalization aspects, the role of local and international partners within the process of internationalization is widely acknowledged in the international business and entrepreneurship studies, that consider networking to be one of the main structural models of cooperation (Holm et al., 1996) and recognize them as a major channel to enter new foreign markets (Johanson and Vahlne, 2009). The relation of such networks with internationalization is particularly emphasized in the international entrepreneurship literature (Kabbara, 2009). However, other studies disagree with this perspective and regard dyadic partnerships to be a more general network construct (Anderson et al.,1994), where dyads are defined as a pair of companies that maintain an exchange relationship. Studies that are represented by dyads and their emerging relationships show how such perspectives can be influential in setting the path, rhythm, speed and scope of the international growth of firms (Zucchella and Kabbara, 2013).

The dimensions of cultural diversity and internationalization can have both positive and negative impacts on team innovation and its performance. According to Kafouros et al. (2008), the process of internationalization can help companies improve their performance through innovation. Various researchers in the field of innovation and international business argue that a company's degree of internationalization (DOI) is the main moderator in the innovation performance relationship (Kotabe et al., 2002). Companies require a specific degree of internationalization in order to have the ability to access a broader range of markets, if they strive to efficiently benefit from their new product and processes. Moreover, it was found that member heterogeneity in teams acts as a catalyst in the idea creation process (Payne, 1990). It was also discovered that the interaction of ethnical diversity and growth strategy influenced important outcomes for a company (Richard et al., 2003). For example, it was demonstrated that within the banking industry the team diversity enhanced the performance for banks that were actively pursuing the innovation strategy (Richard et al., 2003). Some studies have also pointed out at some negative effects: the creativity may be hindered when one team member is more knowledgeable in a specific area than the rest of a team, if a necessary knowledge sharing mechanism is not established (Ochse, 1990).

Having six internationalization aspects tackled from theoretical point of you, these internationalization criteria will be further investigated via quantitative survey (where the correlation analysis is conducted and pertinent recommendations for decision-makers of the analysed firms are provided).

\section{Internationalization strategies and industry characteristics}

The internationalization process is continuously evolving; therefore, a close attention must be paid to the key industry factors that might have an impact on the process of internationalization in terms of speed, geographical scope and/ or entry strategy (Andersson et al., 2014). Moreover, the competition, structure, life cycle, concentration within an industry (along with the knowledge intensity) local cluster internationalization and global industry integration are significant internationalization drivers (Andersson et al.2014). It was also found that the internationalization of new ventures depended on the complexity and variety of the environmental variables (Fernhaber et al., 2007). This was especially the case when Evers (2010) emphasized the importance of the industry structure as an environmental variable and its impact on new venture internationalization processes. The specific industry characteristics can also influence the adopted strategies of companies, especially when such characteristics restrict the choice of available strategic options (Porter, 1986). As a result, these industries reach the competitiveness, stretching from multidomestic to global (Porter, 1986). Companies have been highly dependent on the industry characteristics in the past, as different industries could either create barriers that might hinder international growth, or create drivers that might foster it (Andersson, 2004). 


\section{INSIGHTS INTO REGIONAL DEVELOPMENT}

ISSN 2669-0195 (online) http://jssidoi.org/jesi/

2021 Volume 3 Number 1 (March)

http://doi.org/10.9770/IRD.2021.3.1(3)

Make your research more visible, join the Twitter account of INSIGHTS INTO REGIONAL DEVELOPMENT:

@IntoInsights

Zedtwitz and Gassmann defined two main principal forces in internationalizing the corporate R\&D department (2002). The first force is the access to local markets and customers, while the second one is the access to local science and technology. This is in line with Lauzikas and Miliute (2020), who emphasize the role of R\&D while linking culture and innovation. The authors compare the positive experience of South Korean and Lithuanian IT firms and conclude that the R\&D department could help improve the competitive advantage of a company if a necessary support is provided by other departments. Zedtwitz and Gassmann also discuss the following four major trends (2002): (1) Internationalization of Research, (2) Internationalization of Development, (3) Development follows Research, and (4) Research follows Development. Out of these four trends, companies tend to follow either the first or the second, since opting for internationalization of both (the research and development departments) at the same time will require vast resources from a company (Zedtwitz and Gassmann, 2002). In recent years, the R\&D expenditure lines of foreign-owned companies have seen an increase in both absolute terms and as a share of total business R\&D in the US as well as in nearly all EU countries (Iversen et al., 2016).

In terms of the expansion of a company, small and medium-sized companies gain the knowledge and experience during the process of internationalization, which in turn creates the incentives for the further expansion. This process, however, might explore the available resources, while creating various internal problems (Naldi, 2008). Moreover, some environmental forces may trigger the periods of rapid internationalization or deinternationalization, which might have a strong impact on strategies, utilized by companies in the context of their domestic and overseas' customers and business partners (Crick, 2002).

Moreover, in terms of homogeneous and heterogenous teams, proponents of the team diversity consider that heterogenous teams tend to attract diverse candidates to open positions within their company (O'Leary and Weathington, 2006). They perceive the process of internationalization to be a valuable opportunity for a company in gaining cultural intelligence which plays a vital role in attracting a more diverse base of customers/ clients and partners (O'Leary and Weathington, 2006). Empirical studies tend justify the need for the diversity in companies when observing a positive relationship between the team diversity and problem-solving skills, since heterogeneous teams are often more creative and better at problem solving than homogeneous teams (Konrad, 2003). Konrad emphasises, however, that business cases that are centred on the diversity can have their limitations, since such approaches might lead to the marginalization of the minority groups within a company, where employees might be hired merely to represent a percentage of their respective group (2003).

In terms of digitalization and modern technologies, the empirical studies indicate that the process of internationalization not only promotes the acquisition of new technologies, but also actively contributes to the internal and external growth of a company in international markets (Naldi, 2008). Customers/ clients as well as business partners have higher expectations due to globalization and technological progress. This forces companies to introduce modern technologies into their daily work processes (Kos-Labedowcz, 2013). Kos-Labedowcz states that the main advantage for SMEs (Small-to-Medium Enterprises) is their ability to implement modern technologies in order to increase a company's capability of internal and external communication on a similar level to large enterprises (2013). The technology-driven communication was also scrutinized by Lauzikas and Miliute (2020) in their studies of Lithuanian civil service organizations. The public administration perspective also contributes with the valuable recommendation how to improve the organization's communication with its recipients, suppliers, partners, and even rivals; thus, adding new value to products and service, in light of the age of information (Kos-Labedowcz, 2013).

Innovations are strongly interlinked with social and economic developments and help transform the humanity into prosperity (Szopik-Depczyńska, 2015). The past decade has witnessed a significant increase of the expenditure 


\section{INSIGHTS INTO REGIONAL DEVELOPMENT}

ISSN 2669-0195 (online) http://jssidoi.org/jesi/

2021 Volume 3 Number 1 (March)

http://doi.org/10.9770/IRD.2021.3.1(3)

Make your research more visible, join the Twitter account of INSIGHTS INTO REGIONAL DEVELOPMENT:

@IntoInsights

into innovative activities and the technological change, which had a significant effect on the process, related to presenting the new opportunities for business, economy, and society (Gries et al., 2017). Innovation has a wide variety of interpretations, processes and classification; however, this paper will be centred on team innovation, because the authors aim to quantify the importance of internationalization on individual teams.

\section{Internationalization in the context of innovation}

The concept of innovation has evolved over the last century: it has been a driver for competitiveness in the global marketplace, which constantly required reshaping rules and regulations that deteriorated the economic growth due to a weak innovation culture as well as added a set of new dimensions, such as responsible and ethical innovation (Blok et al., 2017). For instance, the European Commission has encouraged business development and innovative entrepreneurship (2017), while Sternberg (2000) highlighted that developed countries could achieve the long-term growth if innovative products and services were continuously developed. Moreover, the European Union underlined the direction of Innovation Union, which called for the cohesion, sustainability and prosperity via various Research \& Development activities and responsible allocation of available inputs for innovation with bigger social value-added (Blok et al., 2017).

The concept of innovation can refer to individuals, teams, entire companies or economies (Godin 2009). While tackling the evolution of the 'Innovation', Godin explains that the concept of innovation was used to describe the novelties on a very general level (2009): included imitation, invention, creative imagination, and change. Nowadays, however, the concept focuses on two main terminologies: 'Technological Innovation' and 'Commercialized Innovation' (Godin 2009). Such insight is supported by Lauzikas et al. (2016) who examined the service innovation commercialization factors in the fast-food industry. On the other hand, other researchers argue that the concept of Innovation should go beyond the usual intent of generating commercial value due to current global challenges (Blok, 2018).

In comparison to the 'Innovation', the term 'Team innovation' refers to the teams that are ready to specifically develop innovative solutions for a company. Therefore, the team innovation has been gaining its prominence in both the scientific literature and corporate practice, over the past decades (Thayer et al., 2018).

A meta-analysis that was conducted on a team-level showed a stronger relationship between creativity/ innovation and the team process variables, in comparison to input variables, such as the team composition and/ or the team structure (Hülsheger et al., 2009). Hülsheger et al. emphasized that 'Team Innovation' had a particularly significant relationship with certain factors (2009): team size, diversity, goal interdependence, cohesion, internal and external communication, in addition to the four dimensions of the team climate classified by West (1990). Most recently, two essential themes (that tackle team innovation) were proposed by van Knippenberg (2017): (1) the knowledge integration perspective, and (2) the team climate perspective. The first perspective proposes that innovation follows the integration of information, while the second one addresses the innovation diffusion within the team climate and supports the shared commitment towards innovation (van Knippenberg, 2017). Thus, the team innovation can be considered as an important function stemming out of the concept of innovation.

Innovation can be interpreted, based on a vast variety of characteristics and classifications, especially within the internationalization framework. Empirical studies divide innovations into two main fields: (1) the macro level and (2) the micro level (Coccia, 2006). The macro level considers innovation as new to the world, since the innovativeness of companies is dependent on exogenous factors, such as the familiarity of a specific innovation to its relative industry. The micro level, on the other hand, defines innovation as new to companies and their 


\section{INSIGHTS INTO REGIONAL DEVELOPMENT}

ISSN 2669-0195 (online) http://jssidoi.org/jesi/

2021 Volume 3 Number 1 (March)

http://doi.org/10.9770/IRD.2021.3.1(3)

Make your research more visible, join the Twitter account of INSIGHTS INTO REGIONAL DEVELOPMENT:

@IntoInsights

respective consumers. Innovations tend to be classified into various taxonomies (Garcia and Calantone, 2002). DeMarchi (2016), for instance, based on characteristics of certain scientific discoveries and technological innovations. Coccia (2018), however, categorized innovations by the taxonomic characteristics of interactions between different technologies in complex systems. This classification includes four categories: (1) companies that innovate through the acquisition of machinery and equipment, (2) specialized suppliers of capital goods and equipment that are in symbiosis with their customers, (3) science-based companies that exploit scientific discoveries of electronics, chemicals, pharmaceuticals and aerospace, and (4) scale-intensive companies that are involved in the mass production.

The two main traditional types of innovation are considered to be the incremental and the radical innovation (Coccia, 2018), and it is strongly believed that companies need to engage in exploratory and exploitative activities in order to support both incremental and radical innovations (Durisin \& Todorova, 2012).

Kahn et al. emphasized the importance of details within the interpretation of innovation (2003). Indeed, many theoretical frameworks tend to analyse the different characteristics and patterns of technological innovation, but current approaches are still having trouble in explaining certain determinants that help advance incremental and radical innovations in the international markets (Coccia, 2017). Innovation can also be tackled from the perspective of the management of technology (MOT), while Abernathy and Utterback (1985) introduced the classifications, focused on the products, competition, a system of production and the market. They created a map with four main kinds of innovation including: (1) architectural innovation, (2) market niche innovation, (3) regular innovation, and (4) revolutionary innovation. All the above mentions different views and arguments regarding innovation characteristics and their classifications can be used as a groundwork for the development of further sophisticated theories in clarifying technological change (Coccia, 2018).

To continue scrutinizing the innovation development and implementation structure in terms of different departments or functions of a company, a team emerges as a fundamental unit, resulting in the stimulation of innovate ideas as well as increase in their response capacity (Tjosvold et al., 2004). The theory of this strategy explains that the confluence of diverse perspectives, skills and inputs of individual team members facilitates the development of new ideas, especially since the application of these concepts is entirely dependent on the collaboration of team members in a coordinated network (Axtell et al. 2010).

Once the conceived innovation is developed and deemed successful, the company can incorporate it into other teams and departments (Caldwell \& O'Reilly, 2003). As a matter of fact, some companies create specialized innovation teams (IT's) that can be found under various job titles, such as entrepreneurial teams, new venture teams (NVTs), Research \& Development (R\&D) teams, or simply science teams (Thayer et al., 2018). Such teams would naturally have varying responsibilities and would operate in different environments. For instance, Research \& Development teams are usually grouped together even though they tend to experience different risk and uncertainty levels (Bain et al. 2001). New venture teams, on the other hand, tend to create organizational policies and usually have a larger managerial discretion (Klotz et al., 2014), notwithstanding that all the above-mentioned dimensions, innovation teams have a common goal of developing and implementing new innovative products, processes and solutions (Thayer et al., 2018).

The process of innovation in individual teams can be influenced by many factors including: (1) leadership, (2) team characteristics, (3) team composition, and (4) external demand factors (González-Romá, 2008). These factors have been studied as part of empirical researches and highlighted in similar theoretical models with respect to innovation in individual teams (Anderson et al., 2004). Leadership is an essential factor in the innovation 
INSIGHTS INTO REGIONAL DEVELOPMENT

ISSN 2669-0195 (online) http://jssidoi.org/jesi/

2021 Volume 3 Number 1 (March)

http://doi.org/10.9770/IRD.2021.3.1(3)

Make your research more visible, join the Twitter account of INSIGHTS INTO REGIONAL DEVELOPMENT:

@IntoInsights

process in individual teams, since the team leaders tend to have a significant influence on the perception, affective responses, behaviours and performance of team members (Schaubroeck et al., 2007). In terms of team characteristics, González-Romá (2008) defines team members as a group of individuals that carry out specific tasks within a company. These tasks might strengthen the autonomy of individual teams and provide opportunities for learning, developing and social interaction; thus, influencing the team's level of task-orientation and resulting in an intrinsic motivation (González-Romá, 2008).

While drawing the attention to the team composition, the last few decades have seen a multitude of researches that explored the composition of teams through various indicators of diversity (van Knippenberg \& Schippers, 2007). In general, the diversity within a team refers to the inclusion of employees with a set of diverse attributes. The visible attributes may include race, gender and age, while the invisible attributes may include personality, values, education and area of specialization. It is reasonably assumed that individual teams are much better disposed to develop innovative solutions when they possess a greater range of cognitive resources, such as information, knowledge, opinions, perspectives, in addition to the competences (Webber \& Donahue, 2001). The individual teams must also keep innovating when being triggered by constant external demand factors, threats and uncertainties, such as the competition and time pressure (West, 2002). West argues that these external demand triggers play a vital motivational role in modifying the status quo in addition to certain patterns of functioning; thus, provoking the resistance of institutions and organizations that feel threatened by innovation (2002). Therefore, teams that fail to innovate and keep up with the external demand factors may lead to the downfall of their companies (Panne et al. 2003). On the other hand, the current trends in the market, such as the emergence of new technologies, the focus on strategic collaboration and resource sharing, social value-added and sustainability, sophisticated data and knowledge management as well as business intelligence techniques, encourage firms stepping out of comfort zone, breaking schema of thinking and rapidly adapting the newest communication technologies via creativity enhancement, leadership, innovative HR and R\&D strategies or new holistic digital approaches to team innovation management.

\section{Methodology: quantitative approach to team innovation in the context of internationalization}

A wide variety of research disciplines, numerous studies and cases have extensively tackled the field of innovation; however, the experiences of scrutinizing innovation commercialization process in SMEs are still rather fragmented (Gronum et al. 2012; Omarkhanova et. al., 2020).

The present paper is centred on the review of scientific literature sources, then similar research methodologies are compared in order to prepare the questionnaire, to collect and smoothly interpret the descriptive data as well as reveal correlation analysis results in a structured and efficient way. To better structure the results, the conceptual model is developed after the scientific literature review (see the figure 1), which is later on tested while applying the hypotheses. The conceptual model is built on three pillars: internationalization criteria (that are more tangible and less subjective), perception-based intermediary factors (employees' perception on aspects from the creativity enhancement and decision-making to leadership and technology-driven collaboration), and the internationalization effects in terms of team innovation, effectiveness, efficiency and creativity. 
Make your research more visible, join the Twitter account of INSIGHTS INTO REGIONAL DEVELOPMENT: @IntoInsights

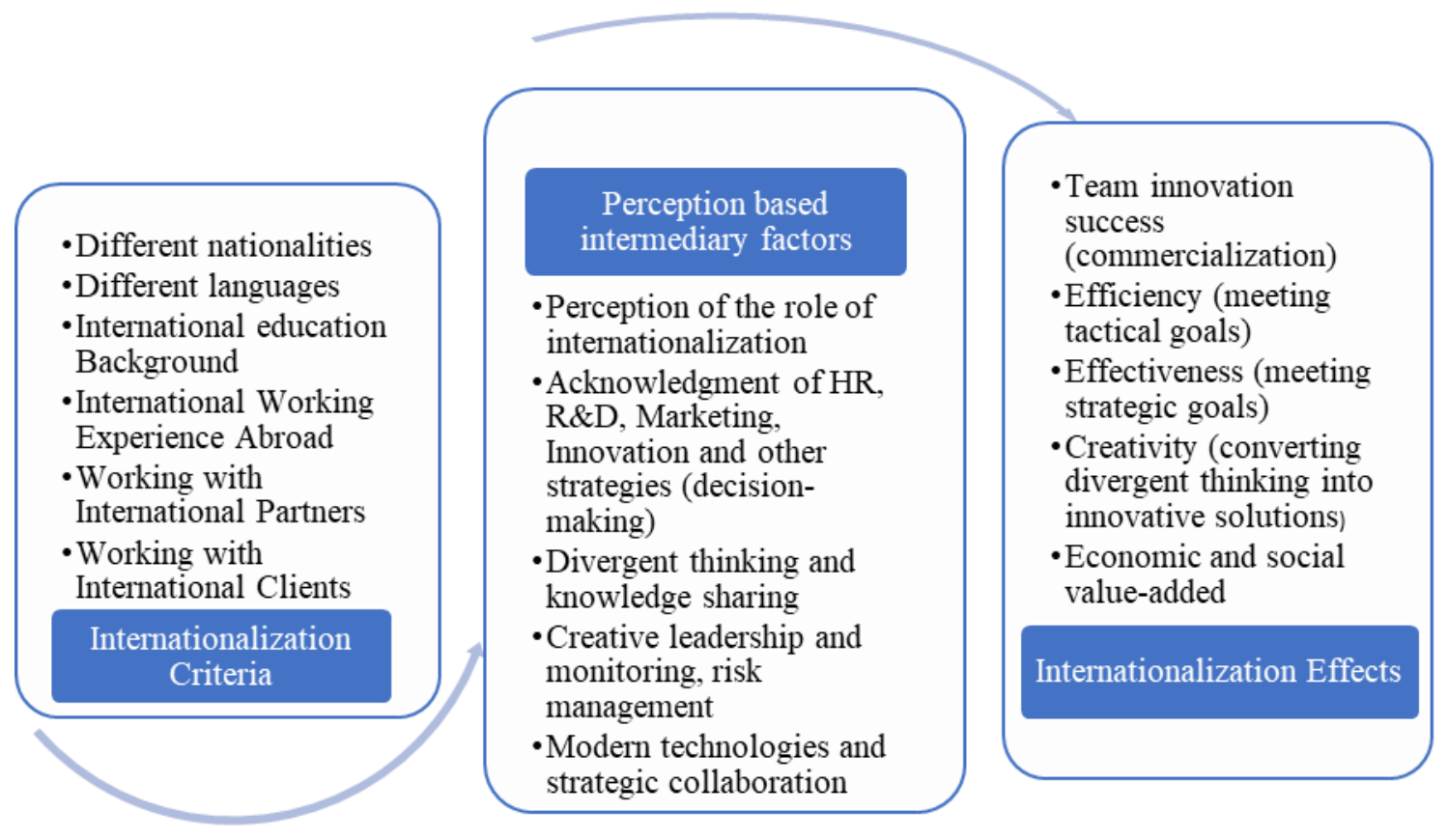

Fig. 1. Conceptual model of internationalization effects on team innovation via perception-based factors Source: developed by the paper authors, based on the literature review

The process of commercialization could be defined as generating a commercial value from innovative products, processes, and services (Herdman, 1995), which differs from a creative idea and is oriented to gaining a competitive advantage in the marketplace. Small companies may become ideas generators for the development of new technologies that can also contribute to the development of larger companies (Libaers et al. 2016). Balancing between exploration and exploitation processes is quite difficult for small companies (Voss \& Voss, 2013), especially when they have limited skills, experience, capabilities, and most importantly, insufficient access to financial capital, particularly in the context of internationalization and expansion, which is accelerating thanks to modern technologies and digitalization (Berends et al., 2014). However, these limitations can be overcome if companies focus on the global markets and the open-source models of innovation (Love \& Roper, 2015), where internal skills gaps can be reduced through collaborative networks and complimentary skills.

In terms of experience and knowledge resources, small companies have recently gained the capability of accessing a wide variety of external sources of innovation through the media, such as online communities, crowdsourcing, and Internet Platforms (West \& Bogers, 2013). This access plays a crucial role in team innovation and has a substantial effect on the commercialization process.

Moreover, some scholars considered the effects of innovation to be strongly dependent on the size of a company (Cohen and Klepper, 1996), while others were not able to confirm such an association (Wang and Tsai, 2003). The researchers in technology-management fields, such as Kessler (2003), tend to argue that good infrastructure and understanding technologies result in high-tech companies focusing on integrating their external findings into the development of their products and processes. Kafouros et al. (2008) believe that investing in team innovation allows companies to be more competitive in the global markets and helps them achieve a higher economic 


\section{INSIGHTS INTO REGIONAL DEVELOPMENT}

ISSN 2669-0195 (online) http://jssidoi.org/jesi/

2021 Volume 3 Number 1 (March)

http://doi.org/10.9770/IRD.2021.3.1(3)

Make your research more visible, join the Twitter account of INSIGHTS INTO REGIONAL DEVELOPMENT:

@IntoInsights

performance through the development of new technologies, adaptation of more efficient production techniques and introduction of new products and processes. All these arguments indicate the importance on team innovation and its direct and indirect effects on the process of commercialization, where the development, access and commercialization of knowledge on the global scale help unleash firms' potential in generating bigger economic and social value-added.

To better tackle internationalization impacts on team innovation, the Lithuanian high-tech firms were selected as an object of the investigation. In spite of being a vibrant country with untapped potential in high-tech industries (Keliuotytė-Staniulėnienè \& Smolskytè, 2019), Lithuanian managers and leaders at a team and an organizational level tend to underestimate the importance of internationalization and its impact on diverse thinking, innovation performance and efficiency (Šūmakaris \& Korsakienè, 2017), which can only be accomplished by joining people from various backgrounds. This can ultimately lead to a lack of creativity inside a company, forcing it to spend financial capital while buying innovative solutions from third-party providers. As a result, the lack of team innovativeness can put such companies at risk of over-spending and weakens their competitive advantage. The present paper is based on the assumption that the level of internationalization in such teams has a direct impact on the level of their divergent thinking (team innovation), which in turn has an impact on their innovation performance, efficiency, and ultimately on the process of innovation commercialization.

Employees of 10 high-tech companies in Lithuania (with an average headcount of 20 employees) were contacted via LinkedIn and the primary data was collected while using the multiple-choice and Likert-scale questions. The population size reads 150 employees, while the minimum sample size stands at 108 employees, using a 95\% confidence level and a 5\% confidence interval. In total, 120 responses (above the minimum threshold) were interrogated.

In spite of the quantitative nature of the paper, in line with scholars, such as Jost et al. (2009), the most of respondents' answers were based on their perceptions and unique attitudes, which is particularly important while tackling the role of internationalization on team innovation. Moreover, the primary data from in-depth interviews with experts should be conducted within the next research of the same series. This would also help capture the decision-making process at different hierarchy levels, along with trans-disciplinary and cross-departmental innovation commercialization processes and team innovation specificities.

The aim of this research is to examine the relationship between the level of internationalization and the level of team innovation-related factors, such as creative thinking, innovation performance and efficiency in teams. Driven by the assumption that the level of internationalization in teams has a direct impact on the level of divergent thinking in teams (which leads to team innovation), this paper is also centred on the attempts to tackle the effects of internationalization on the innovation commercialization process.

The questionnaire consisted of 4 blocks of questions: the screening questions helped eliminate the answers of respondents who did not work in teams of high-tech companies; a set of 8 multiple-choice questions contributed to the identification of the internationalization level within a respondent's team; five Likert-scale questions revealed respondents' perception regarding the liaison between internationalization and team creativity (innovation) in their respective team; 5 multiple choice questions gathered the demographic information of respondents. After eliminating $10(8.3 \%)$ respondents, because of their negative answers to at least one of the two screening questions, 110 valid responses were gathered. 
INSIGHTS INTO REGIONAL DEVELOPMENT

ISSN 2669-0195 (online) http://jssidoi.org/jesi/

2021 Volume 3 Number 1 (March)

http://doi.org/10.9770/IRD.2021.3.1(3)

Make your research more visible, join the Twitter account of INSIGHTS INTO REGIONAL DEVELOPMENT:

@IntoInsights

In order to test the theoretical framework model, deriving from the literature review, the null-hypothesis that the process of internationalization has no effect on team creativity, innovation performance and efficiency, was underlined. The following main hypotheses were pointed out: respondents who consider their teams to be more internationalized would also be capable to identify the positive effects of internationalization in terms of team creativity, innovation performance and efficiency.

\section{Research on internationalization effects on team innovation in Lithuanian high-tech firms: employees' perspective}

The descriptive analysis of the internationalization level among respondents' teams led to a rather detailed profile of an employee, team and company, which is critical to statistically analyse the liaison between internationalization and team innovation. More than one third $(36.4 \%)$ of respondents were working in a team composed of 5-8 employees, which is close to the optimal team size of around 6 members, as stated by Beatty and Barker-Scott (2004). Although the distribution of demographic characteristics of respondents in terms of gender ( $40 \%$ of the valid respondents being male, and $60 \%$ being female) were rather in line with the national demographic proportions, the highest valid percentage (66.4\%) of employees in terms of age belonged to the category between 20 and 24 years old, which corresponds to the nature of high-tech firms in Lithuania, driven by young talented researchers and international strategic collaboration. In light of such diverse employees' background, the valid result that nearly one third (26.4\%) of respondents obtained a Bachelor's degree outside Lithuania was not surprising. In addition, one fifth of the interrogated employees (20.9\%) had some experience working outside the country (versus $31.8 \%$ with no international work experience). In line with the origin of international education, $30.9 \%$ of respondents were of a foreign origin (versus $69.1 \%$ - Lithuanian).

It is interesting to note that a combined $50 \%$ of the respondents worked in teams that are larger than the average optimal number, while a mere $14.5 \%$ worked in teams smaller than the optimal average. Moreover, the distribution of answers with respect to different nationalities were in line with the usage of languages (in parallel with nationalities, the highest valid percentages of $36.4 \%$ and $33.6 \%$ respectively indicated 3 languages). Based on the theoretical framework model, international educational background and working experience abroad are critical to success. The survey indicated that teams in high-tech companies had 2-3 members with international educational background and/ or working experience abroad, suggesting that high-tech companies understood the potential of gaining valuable expertise though both the available national and international labour supply. The descriptive results revealed that teams have a unique potential of gaining valuable feedback from their international partners and clients in order to improve their products and services: on average half of the indicated partners were international, and the great majority of the employees characterised their clients as international.

Taken into account that internationalization manifests in teams in different ways and forms, our survey focused more on team innovation success, and first of all, on the main barriers to the innovation performance: c.a. one half of the valid respondents $(50.9 \%)$ considered a lack of international working experience one of the biggest barriers to the innovation process in a team, with $44.5 \%$ of the respondents believing that this is due to a lack of connections with international business partners and $40 \%$ believing that this is due to the absence of international educational background. Surprisingly, only $15.5 \%, 20 \%$ and $29 \%$ of all the valid respondents considered a small pool of nationalities, a small pool of languages and a lack of connections with international clients (respectively) to be the biggest barriers to the innovation process in a team. 
INSIGHTS INTO REGIONAL DEVELOPMENT

ISSN 2669-0195 (online) http://jssidoi.org/jesi/

2021 Volume 3 Number 1 (March)

http://doi.org/10.9770/IRD.2021.3.1(3)

Make your research more visible, join the Twitter account of INSIGHTS INTO REGIONAL DEVELOPMENT:

@IntoInsights

110 responses

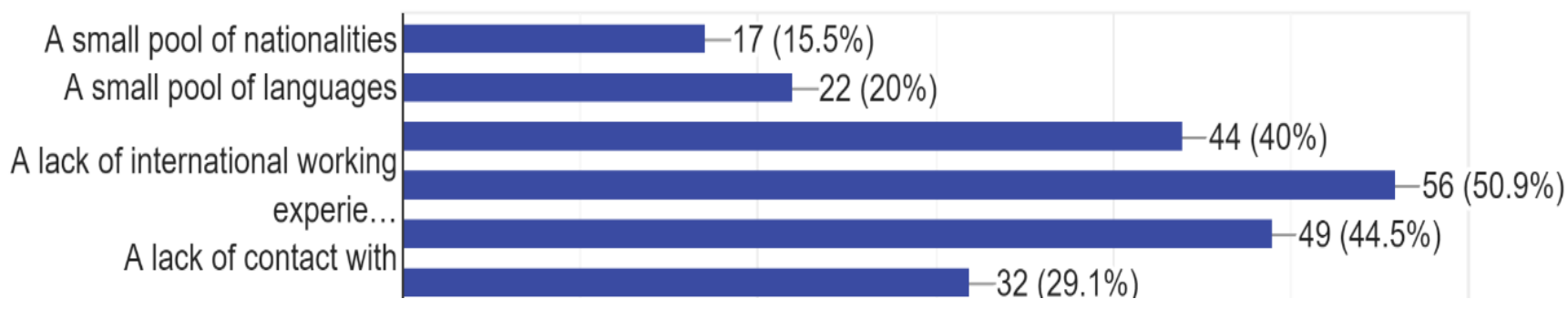

Fig. 2. The barriers to team innovation

Source: Developed by the paper authors, based on the research results

In addition to the identified barriers, international working experience, working with international partners, and working with international clients were considered the key criteria to encourage divergent thinking and team creativity (team innovation).

\section{Correlation Analysis}

Respondents who consider their team largely internationalized tend to believe that the six internationalization criteria (Different Nationalities, Different Languages, International Education Backgrounds, International Working Experience Abroad, Working with International Partners, Working with International Clients) are very important for their team's creativity, while respondents who characterize their team as not internationalized diminish the role of internationalization factors. From the produced correlation matrix, the relevant correlations are only the ones where each criterion of one row meets the same criterion in a column, while the rest of the correlations can be discarded. Even though the relevant correlations are positive, the relationships are considered to be weak (a correlation of $0.2-0.4$ ). Moreover, out of the 6 relevant correlations that are highlighted in table 1 , four of them have a significance level of 0.05 or less, meaning that these correlations are statistically significant. This correlation suggests that the more internationalized a respondent's team is, the more they see how important the internationalization criteria actually are for their team's creativity.

Moreover, respondents who consider their team very internationalized tend to indicate that the previously mentioned internationalization criteria are very important for their team's innovation performance and efficiency, while respondents who characterise their team as less internationalized do not find the internationalization criteria of significant importance. Within these positive relationships the rows represent the level of internationalization in a respondent's team, while the columns represent the importance of internationalization for team's innovation performance and efficiency. From the produced correlation matrix, the relevant correlations are again only the ones where each criterion of one row meets the same criterion in a column, while the rest of the correlations can be discarded. Most of the relevant correlations are positive, where a correlation between 0.2-0.4 is considered to be weak and a correlation between 0.4-0.6 is average. Moreover, out of the 6 relevant correlations, five of them have a significance level of 0.05 or less, meaning that these correlations are statistically significant (see Table 2). 


\section{INSIGHTS INTO REGIONAL DEVELOPMENT}

ISSN 2669-0195 (online) http://jssidoi.org/jesi/

2021 Volume 3 Number 1 (March)

http://doi.org/10.9770/IRD.2021.3.1(3)

Make your research more visible, join the Twitter account of INSIGHTS INTO REGIONAL DEVELOPMENT:

@IntoInsights

This correlation suggests that the more internationalized a respondent's team is, the more they acknowledge the role of the internationalization criteria on a team's innovation performance and efficiency.

Finally, respondents who believe that the six internationalization criteria are very important for their team's creativity also tend to believe that these criteria are very important for their team's innovation performance and efficiency. The rows represent the importance of internationalization for team creativity and the columns represent the importance of internationalization for team performance and efficiency. All of the relevant correlations are positive, where a correlation between $0.4-0.6$ is considered to be average and a correlation between $0.6-0.8$ is considered to be strong. Moreover, all the 6 relevant correlations that are highlighted in the Table 3 have a significance level of 0.05 or less, meaning that the relevant correlations are statistically significant. This correlation suggests that respondents strongly associate the interrelationship between the role of internationalization and both team innovation, efficiency (which leads to commercialization) and creativity.

\section{Conclusions and Recommendations}

Driven by the aim to investigate the relationship between the level of internationalization and the level of creative thinking/ innovation performance and efficiency in teams (built by high-tech companies in Lithuania), the qualitative research was conducted. Its results helped unlock the internationalization potential within team innovation processes while strengthening the competitive advantages of the analysed companies.

The results of the correlation analysis confirm that employees who consider their team very internationalized tend to indicate that the previously mentioned internationalization criteria are very important for their team's creativity. Moreover, employees who consider their team internationalized tend to believe that the previously mentioned internationalization criteria are very important for their team's innovation performance and efficiency. Last but not least, employees who believe that six internationalization criteria are very important for their team's creativity also willing to believe that these criteria are very important for their team's innovation performance and efficiency.

To conclude, the research findings indicated a weak positive correlation between internationalization and team creativity (innovation), an average positive correlation between internationalization and innovation performance, and a strong positive relationship between team creativity and innovation performance. Therefore, high-tech companies are highly recommended to actively pursuit the internationalization of their teams, if they aim to stay competitive and mitigate the risk in terms of third-party service (ideas, knowledge, and etc.) providers. This could be achieved via more innovative and open HR strategies, while recruiting employees with international experience and foreign educational background, training team members and reshaping their perception, in parallel with modern technologies (such as shared value digital platforms) that provide the opportunities to transactionally communicate with international clients and partners in order to create a bigger synergy effect.

A future research could be conducted while applying a qualitative research method and using in-depth interviews with experts (top decision-makers) of Lithuanian high-tech companies or analysing industries of lower technological intensity firms in different countries. A set of concrete indicators how to measure internationalization effects on team innovation could be identified and used in HR technology solutions, oriented to team innovation improvement matrix, which could be further customized, based on the business development cycle, specificity of business model, industry development trends, management and leadership style, as well as the main strategic targets of a company, along with available inputs and expected outputs in different time perspectives. 
INSIGHTS INTO REGIONAL DEVELOPMENT

ISSN 2669-0195 (online) http://jssidoi.org/jesi/

2021 Volume 3 Number 1 (March)

http://doi.org/10.9770/IRD.2021.3.1(3)

Make your research more visible, join the Twitter account of INSIGHTS INTO REGIONAL DEVELOPMENT:

@IntoInsights

\section{References}

Abernathy, W.J.; Utterback, J.M. (1985). Patterns of industrial innovation, in Technological Review, No. 50, pp. 41-47, https://www.academia.edu/23341473/Patterns_of_Industrial_Innovation

Andersen, O. (1993). On the internationalization process of firms: A critical analysis. Journal of International Business Studies. Vol. 24 No. 2, $\quad$ p. $209 . \quad$ https://www.semanticscholar.org/paper/On-the-Internationalization-Process-of-Firms\%3A-A$\underline{\text { Andersen/dafcd50c9a09f5513c541b58e42d379cfaeaaa7b }}$

Andersen, O. (1997). Internationalization and market entry mode: A review of theories and conceptual frameworks. Management International Review. Vol. 37 No. 2, pp. 27-42, ISSN:0025-181X

Anderson, J. C.; Hakansson, H.; Johanson, J. (1994). Dyadic business relationships within a business network context, Journal of Marketing, Vol. 58, No. 4, pp.1-15. https://doi.org/10.2307/1251912

Anderson, N.; De Dreu, C. K. W.; Nijstad, B. A. (2004). The routinization of innovation research: A constructively critical review of the state-of-the-science. Journal of Organizational Behavior, Vol. 25 No. 2, pp. 147-173. http://doi.org/10.1002/job.236

Andersson, S. (2004). Internationalization in different contexts, Journal of Business Venturing, Vol. 19 No. 6, pp. 851-875. http://www.sciencedirect.com/science/article/pii/S0883-9026(03)00115-0

Andersson, S.; Evers, N.; Kuivalainen, O. (2014). International new ventures: rapid internationalization across different industry contexts. European Business Review, Vol. 26 No.5, pp. 390-405. http://doi.org/10.1108/EBR-05-2014-0040

Axelsson, B./Easton, G. (1992). Industrial Networks: A New View of Reality, London: Routledge, ISBN 9781138642959, p. 283

Axtell, C.; Holman, D.; Wall, T. (2010). Promoting innovation: A change study. Journal of Occupational and Organizational Psychology, Vol. 79, pp. 509-516 https://doi.org/10.1348/096317905X68240

Bain, P. G.; Mann, L.; Pirola-Merlo, A. (2001). The innovation imperative: The relationships between team climate, innovation, and performance in research and development teams. Small Group Research Vol. 32, pp. 55-73 http://dx.doi.org/10.1177/104649640103200103

Beamish, P.W. (1990). The Internationalisation Process of Small Ontario Firms: a Research Agenda. In Rugman, Alan M, editor, Research in Global Strategic Management -International Business Research for the Twenty First Century: Canada's New Research Agenda. Greenwich: JAI Press Inc. pp. 77-92.

1Beatty, C. A.; Barker-Scott, B.A. (2004). Building smart teams. A roadmap to high performance. California: Sage Publications, Inc. p. 208 ISBN-13: 978-0761929567 ISBN-10: 0761929568

1Begeny, J. C. (2018). An overview of internationalization and its relevance for school and educational psychology. Psychology in the Schools, Vol. 55 No. 8, pp. 897-907. https://doi.org/10.1002/pits.22161

1Bell, J. (1995). The Internationalisation of Small Computer Software Firms - A Further Challenge "Stage" Theories, European Journal of Marketing, Vol. 29 No. 8, pp. 60-75 https://www.deepdyve.com/lp/emerald-publishing/the-internationalization-of-small-computersoftware-firms-a-further-0vmjFHM7h0

Benito, G.R.G.; Welch, L.S. (1994). Foreign Market Servicing: Beyond Choice of Entry Mode. Journal of International Marketing, Vol. 2 No. 2:7 https://doi.org/10.1177/1069031X9400200202

Berends, H.; Jelinek, M.; Reymen, I.; Stultiëns, R. (2014). Product innovation processes in small firms: Combining entrepreneurial effectuation and managerial causation. Journal of Product Innovation Management, Vol. 31 No.3, pp. 616-635

Bilkey, W. J.; Tesar, G. (1977). The Export Behavior Of Smaller-Sized Wisconsin Manufacturing Firms, Journal of International Business Studies: Palgrave Macmillan Ltd. Vol. 8 No.1 pp. 93-98. http://doi.org/10.1057/palgrave.jibs.8490783 
INSIGHTS INTO REGIONAL DEVELOPMENT

ISSN 2669-0195 (online) http://jssidoi.org/jesi/

2021 Volume 3 Number 1 (March)

http://doi.org/10.9770/IRD.2021.3.1(3)

Make your research more visible, join the Twitter account of INSIGHTS INTO REGIONAL DEVELOPMENT:

@IntoInsights

1Blok, V. (2018). Philosophy of Innovation: A Research Agenda. Philosophy of Management. Vol. 17 pp. $1-5$ https://doi.org/10.1007/s40926-017-0080-z

1Blok, V.; Tempels, T.; Pietersma, E.; Jansen, L. (2017). Exploring ethical decision making in responsible innovation: The case of $\begin{array}{lllllll}\text { innovations for healthy } & \text { food. } & \text { Responsible } & \text { Innovation } & 3 \text {, 209-230 }\end{array}$ https://www.researchgate.net/publication/320204111_Exploring_Ethical_Decision_Making_in_Responsible_Innovation_The_Case_of_Inn ovations_for_Healthy_Food

Bužavaitė, M.; Ščeulovs, D.; Korsakienè, R. (2019). Theoretical approach to the internationalization of SMEs: future research prospects based on bibliometric analysis, Entrepreneurship and Sustainability Issues. Vol. 6 No.3 pp. 1497-1511 https://doi.org/10.9770/jesi.2019.6.3(31)

Caldwell, D. F.; O'Reilly, C. A. (2003). The determinants of team-based innovation in organizations - the role of social influence. Small Group Research, Vol. 34 No. 4, pp. 497-517 https://doi.org/10.1177/1046496403254395

Chetty, S.; Campbell-Hunt, C. (2004). A Strategic Approach to Internationalization: A Traditional Versus a "Born-Global" Approach. Journal of International Marketing, Vol. 12 No. 1, pp. 57-81. https://doi.org/10.1509/jimk.12.1.57.25651

Coccia, M. (2006). Classifications of innovations: survey and future directions. Working Paper Ceris del Consiglio Nazionale delle Ricerche, Vol.8 No. 2, pp. 1-19. http://doi.org/10.2139/ssrn.2581746

Coccia, M. (2017) Sources of technological innovation: Radical and incremental innovation problem-driven to support competitive advantage of firms, Technology Analysis \& Strategic Management, Vol. 29 No. 9, pp.1048-1061. http://doi.org/10.1080/09537325.2016.1268682

Coccia, M. (2018). Classification of innovation considering technological interaction. Journal of Economics Bibliography. Vol. 5, No. 2, p. 94. http://doi.org/10.1453/jeb.v5i2.1650

Cohen, W.; Klepper, S. (1996). A Reprise of Size and R \& D. The Economic Journal, Vol. 106 No. 437, pp. 925-951. http://doi.org/10.2307/2235365

Coviello, N. E. (2006). The network dynamics of international new ventures. Journal of International Business Studies, Vol. 37 No.5 pp. 713-31 https://www.jstor.org/stable/4540377

Coviello, N.; Munro, H. (1997). Network relationships and the internationalisation process of small software firms. International Business Review. Vol. 6, No. 4. No.2 pp. 361-386. http://www.sciencedirect.com/science/article/pii/S0969593197000103

Coviello, N.E; McAuley, A. (1999). Internationalisation and the Smaller Firm: A Review of Contemporary Empirical Research., Management International Review (MIR). Third Quarter 1999; ABI/INFORM Global p. 223 https://www.researchgate.net/profile/Nicole_Coviello/publication/275098447_Internationalisation_and_the_Smaller_Firm_A_Review_of_ Contemporary_Empirical_Research/links/553270580cf2f2a588aef6f1/Internationalisation-and-the-Smaller-Firm-A-Review-of-

Contemporary-Empirical-Research.pdf

Cox, T.; \& Blake, S. (1991). Managing cultural diversity: Implications for organizational competitiveness. Academy of Management Executive, Vol. 5 No.3 pp. 45-56. https://doi.org/10.5465/ame.1991.4274465

Crick, D. (2002) The Decision to Discontinue Exporting: SMEs in two UK Trade Sectors, Journal of Small Business Management, Vol. 40 No. 1, pp. 66-77 https://doi.org/10.1111/1540-627X.00040

DeMarchi, M. (2016). First steps towards a consistent classification of innovation. Scientometrics, Vol. 108 No. 2, pp. 983-985. http://doi.org/10.1007/s11192-016-1994-2

Doz, Y.; Santos, J.; Williamson, P. (2001). From Global to Metanational: How Companies Win in the Knowledge Economy, Ubiquity, December Issue. http://doi.org/10.1145/503117.503119 
INSIGHTS INTO REGIONAL DEVELOPMENT

ISSN 2669-0195 (online) http://jssidoi.org/jesi/

2021 Volume 3 Number 1 (March)

http://doi.org/10.9770/IRD.2021.3.1(3)

Make your research more visible, join the Twitter account of INSIGHTS INTO REGIONAL DEVELOPMENT:

@IntoInsights

Durisin, B.; Todorova, G. (2012). A Study of the Performativity of the "Ambidextrous Organizations. Theory: Neither Lost in nor Lost before Translation. Journal of Product Innovation Management Vol. 29 No.S1, pp. 53-75. https://doi.org/10.1111/j.1540$\underline{5885.2012 .00981 . x}$

European Commission (2017). Innovation Union. Available onine: http://ec.europa.eu/research/innovation-union/index_en.cfm?pg=why (last accessed 28-May-2020).

Evers, N. (2010). Factors influencing the internationalization of new ventures in the Irish aquaculture industry: an exploratory study, Journal of International Entrepreneurship, Vol. 8 No. 4, pp. 392-416. http://doi.org/10.1007/s10843-010-0065-7

Fernhaber, S.; McDougall, P.P.; Oviatt, B.M. (2007). Exploring the role of industry structure in new venture internationalization, Entrepreneurship Theory \& Practice, Vol. 31 No. 4, pp. 517-542. https://doi.org/10.1111/j.1540-6520.2007.00186.X

Garcia, R.; Calantone, R. (2002). A critical look at technological innovation typology and innovativeness terminology: a literature review, in The Journal of Product Innovation Management, No. 19, pp. 110-132. https://doi.org/10.1111/1540-5885.1920110

Godin, B. (2009). Innovation: The history of a category. Working paper, p. 67, http://www.csiic.ca/PDF/IntellectualNo1.pdf

Gollnick, D.; Chinn, P. (2006). Multicultural education in a pluralistic society. Upper Saddle River, NJ: Merrill Prentice Hall, p. 32 http://sullivanc-module.weebly.com/uploads/1/6/5/2/16522976/multicultural_education.pdf

González-Romá, V. (2008). Innovation in work teams. Papeles del Psicólogo, Vol. 29, Vol. 1, pp. 32-40 https://www.researchgate.net/publication/242279935_Innovation_in_work_teams/link/54b6fb970cf24eb34f6e9938/download

Gries, T.; Grundmann, R.; Palnau, I.; Redlin, M. (2017). Innovations, growth and participation in advanced economies-a review of major concepts and findings. International Economics and Economic Policy. Vol. 14 No. 2 pp. 293-351 https://doi.org/10.1007/s10368-016-0371$\underline{1}$

Gronum, S.; Verreynne, M. L.; Kastelle, T. (2012). The role of networks in small and medium sized enterprise innovation and firm performance. Journal of Small Business Management, Vol. 50, No. 2, pp. 257-282 https://doi.org/10.1111/j.1540-627X.2012.00353.X

Herdman, R. C. (1995). Innovation and commercialisation of emerging technologies. Washington: Printing Office of Technology Assessment, p.102 https://www.princeton.edu/ ota/disk1/1995/9539/9539.PDF

Hislop, D. (2002) The Client Role in Consultancy Relations During the Appropriation of Technalngical Innovations' Research Palicy Vol. 31, No. 5, pp. 657-71. http://www.sciencedirect.com/science/article/pii/S0048-7333(01)00135-4

Holm, D. B.; Eriksson, K.; Johanson, J. (1996). «Creating value through mutual commitment to business network relationships », Strategic Management Journal. Vol. 20, No. 5, pp.467- 486. https://www.jstor.org/stable/3094165

Hülsheger, U. R.; Anderson, N.; Salgado, J. F. (2009). Team-level predictors of innovation at work: A comprehensive meta-analysis spanning three decades of research. Journal of Applied Psychology, Vol. 94, pp. 1128 -1145 http://dx.doi.org/10.1037/a0015978

Iversen, E.; Dachs, B.; Poti, B.; Patel, P.; Cerulli, G.; Spallone, R.; Zahradnik, G.; Knell. M.; Scherngell, T.; Lang, F. (2016). Internationalisation of business investments in R\&D and analysis of their economic impact (BERD Flows). Luxembourg: European Commission. p. 172. http://doi.org/10.02777/888034

Johanson, J.; Mattsson, L.G. (1988). Internationalisation in Industrial Systems -a Network Approach. In Hood, N \& Jan-Erik Vahlne, editors, Strategies in Global Competition. London: Croom Helm. pp. 287-314. http://doi.org/10.1057/jibs.2009.24

Johanson, J.; Vahlne, J.E. (2009). The Uppsala internationalization process model revisited: from liability of foreignness to liability of outsidership. Journal of International Business Studies, Vol. 40 No. 9 pp. 1411-1431. http://www.palgravejournals.com/jibs/journal/v40/n9/pdf/jibs200924a.pdf

Jost, J. T.; Rudman, L. A.; Blair, I. V.; Carney, D. R.; Dasgupta, N.; Glaser, J.; Hardin, C. D. (2009). The existence of implicit bias is beyond reasonable doubt: A refutation of Ideological and methodological objections and executive summary of ten studies that No manager should ignore. Research in Organizational Behavior, Vol. 29, pp. 39 - 69 http://dx.doi.org/10.1016/j.riob.2009.10.001 
INSIGHTS INTO REGIONAL DEVELOPMENT

ISSN 2669-0195 (online) http://jssidoi.org/jesi/

2021 Volume 3 Number 1 (March)

http://doi.org/10.9770/IRD.2021.3.1(3)

Make your research more visible, join the Twitter account of INSIGHTS INTO REGIONAL DEVELOPMENT:

@IntoInsights

Kabbara, D. (2009). Evolutionary Network Process of International Entrepreneurial Firm, International Journal of Globalization and Small Business, Vol. 3, No 3, pp. 346-370. https://doi.org/10.1504/IJGSB.2009.024576

Kafouros, M.I.; Buckley, P.J.; Sharp, J.A. et al. (2008). The role of internationalization in explaining innovation performance. Technovation Vol. 28 No. 1-2, pp. 63-74. http://dx.doi.org/10.1016/j.technovation.2007.07.0...

Kahn, K.B.; Franzak, F.; Griffin, A.; Kohn, S.; Miller, C.W. (2003), Editorial: Identification and consideration of emerging research questions, Journal of Product Innovation Management, Vol. 20, pp. 193-201

Keliuotytė-Staniulèniené, G.; Smolskytè, G. (2019). Possibilities for Financial Technology Sector Development and its Impact on Banking Sector Profitability in Lithuania, Economics and Culture, Vol.16, No.1, pp. 12-23. https://doi.org/10.2478/jec-2019-0002

Kessler, E.H. (2003). Leveraging e-R\&D processes: a knowledge-based view. Technovation Vol. 23, pp. 905-915 https://citeseerx.ist.psu.edu/viewdoc/download?doi=10.1.1.110.4284\&rep=rep1\&type=pdf

Klotz, A. C.; Hmieleski, K. M.; Bradley, B. H.; Busenitz, L. W. (2014). New venture teams: A review of the literature and roadmap for future research. Journal of Management, Vol. 40, pp. 226 -255. http://dx.doi.org/10.1177/0149206313493325

Konrad, A. M. (2003). Defining the domain of workplace diversity scholarship. Group \& Organization Management, Vol. 28, pp. 4-17. https://doi.org/10.1177/1059601102250013

Kos-Labędowicz, J. (2013). Influence of Modern Technologies on Internationalization of Small and Medium Enterprises. Information Systems in Management Vol. 2 No. 1, pp. 12-22. file:///C:/Users/minda/AppData/Local/Temp/ISIM_Vol_2(1)_12-22.pdf

Kotabe, M.; Srinivasan, S. S.; Aulakh, P. S. (2002). Multinationality and firm performance: The moderating role of R\&D and marketing capabilities. Journal of International Business Studies, Vol. 33 No.1, pp. 79-97. 33 https://doi.org/10.1057/palgrave.jibs.8491006

Kumar, V.; Subramanian, V. (1997). A contingency framework for the mode of entry decision. Journal of World Business, Vol. 32 No. 1, pp. 53-72. https://doi.org/10.1016/S1090-9516(97)90025-0

Laužikas, M.; Miliūtè, A. (2020). Liaisons between culture and innovation: comparative analysis of South Korean and Lithuanian IT companies. Insights into Regional Development, Vol. 2 No.2, pp. 523-537 https://doi.org/10.9770/IRD.2020.2.2(2)

Laužikas, M.; Miliūtè, A. (2020). Impacts of modern technologies on sustainable communication of civil service organizations. Entrepreneurship and Sustainability Issues, Vol. 7 No. 3, pp. 2494-2509 https://doi.org/10.9770/jesi.2020.7.3(69)

Lauzikas, M.; Miliūtè, A.; Tranavicius, L.; Kiciatovas, E. (2016). Service Innovation Commercialization Factors in the Fast Food Industry, Entrepreneurship and Sustainability Issues, Vol. 4 No. 2, pp. 108-128. http://dx.doi.org/10.9770/jesi.2016.4.2(1)

Libaers, D.; Hicks, D.; Porter, A. L. (2016). A taxonomy of small firm technology commercialization. Industrial and Corporate Change, Vol. 25 No.3, pp. 371-405 http://hdl.handle.net/10.1093/icc/dtq039

Loane, S.; McNaughton, R.B.; Bell, J. (2004). The Internationalization of Internet-Enabled Entrepreneurial Firms: Evidence from Europe and North America, Canadian Journal of Administrative Sciences. Vol. 21 No. 1, pp. 79 - 96. http://doi.org/10.1111/j.1936$\underline{4490.2004 . t b 00324 . x}$

López-Duarte, C.; Vidal-Suárez, M. (2010). External uncertainty and entry mode choice: Cultural distance, political risk and language

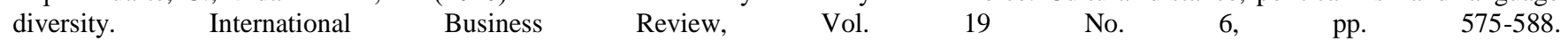
http://www.sciencedirect.com/science/article/pii/S0969593110000351

Love, J. H.; Roper, S. (2015). SME innovation, exporting and growth: A review of existing evidence. International Small Business Journal, Vol. 33 No.1, pp. 28-48. https://doi.org/10.1177/0266242614550190

Maznevski, M. L. (1994). Understanding our differences: Performance in decision-making groups with diverse members. Human relations, Vol. 47, pp. 531-552. https://doi.org/10.1177/001872679404700504 


\section{INSIGHTS INTO REGIONAL DEVELOPMENT}

ISSN 2669-0195 (online) http://jssidoi.org/jesi/

2021 Volume 3 Number 1 (March)

http://doi.org/10.9770/IRD.2021.3.1(3)

Make your research more visible, join the Twitter account of INSIGHTS INTO REGIONAL DEVELOPMENT:

@IntoInsights

Morgan, R.E.; Katsikeas, C.S. (1997). Theories of international trade, foreign direct investment and firm internationalization: a critique. Management Decision, Vol. 35 No. 1, pp. 68-78 https://doi.org/10.1108/00251749710160214

Naldi, L. (2008), Growth through Internationalization. A Knowledge Perspective on SMES, Jönköping: Jönköping International Business School. https://www.researchgate.net/publication/277751927_Growth_through_Internationalization_A_Knowledge_Perspective_on_SMEs

O’Leary, B. J.; Weathington, B. (2006). Beyond the Business Case for Diversity in Organizations. Employee Responsibilities and Rights Journal, Vol. 18 No.4, pp. 283-292. http://doi.org/10.1007/s10672-006-9024-934

Ochse, R. (1990). Before the gates of excellence: The determinants of creative genius. Cambridge; NY: Cambridge University Press. ISBN 10: 0521376998ISBN 13: 9780521376990

O'Farrell, P. N.; Wood, P. A.; Zheng, J. (1998). Internationalisation by Business Service SMEs: An Interindustry Analysis, International Small Business Journal, Vol.16, No. 2, pp. 13-31. https://doi.org/10.1177/0266242698162001

Omarkhanova, Zh.; Tleuzhanova, D.; Zholmukhanova, A.; Mukhambetova, Z. 2020. Comparative analysis of social and economic efficiency in managing product innovations in the pharmacetic industry. Entrepreneurship and Sustainability Issues, 8(2), 1245-1266. http://doi.org/10.9770/jesi.2020.8.2(74)

Onkelinx, J.; Manolova, T. S.; Edelman, L. F. (2016). Human capital and SME internationalization: Empirical evidence from Belgium. International Small Business Journal, Vol. 34 No.6, pp. 818-837. https://doi.org/10.1177/0266242615591856

Østergaarda C. R.; Timmermans, B.; Kristinsson, K. (2011). Does a different view create something new? The effect of employee diversity on innovation. Research Policy, No. 40, pp. 500-9. https://ideas.repec.org/a/eee/respol/v40y2011i3p500-509.html

Oviatt, B.M.; McDougall, P.P. (2005). Defining international entrepreneurship and modeling the speed on internationalization. Entrepreneurship theory and practice, Vol. 29, No.5, pp. 537-553. https://doi.org/10.1111/j.1540-6520.2005.00097.x

Panne, G.; Beers, C.; Kleinknecht, A. (2003). Success and failure of innovation: a literature review. International Journal of Innovation Management, Vol. 7 No. 3, pp. 309-338 http://dx.doi.org/10.1142/S1363919603000830

Payne, R. (1990). The effectiveness of research teams: A review. In M. A. West \& J. L. Farr (Eds.), Innovation and creativity at work, pp. 101-122. Chichester, UK: Wiley. https://psycnet.apa.org/record/1991-97989-005

Porter, M.E. (1986), Competition in Global Industries, Harvard Business School Press, Boston, MA.

Priem, R. L. (1990). Top management team group factors, consensus, and firm performance. Strategic Management Journal, No.11, pp. 469-478. https://doi.org/10.1002/smj.4250110605

Quintana-Garca, C.; Benavides-Velasco, C.A. (2008). Innovative competence, exploration and exploitation: the influence of technological diversification. Research Policy, Vol. 37 No. 3, pp. 492-507. http://doi.org/10.1016/j.respol.2007.12.002

Rennie, M.W. (1993). Global Competitiveness: Born Global, The McKinsey Quarterly, 4, pp. 45-52.

Richard, O.; McMillan, A.; Chadwick, K.; Dwyer, S. (2003). Employing an innovation strategy in racially diverse workforces: Effects on firm performance. Group and Organization Management, Vol. 28, pp.107-126. https://doi.org/10.1177/1059601102250022

Saarenketo, S.; Puumalainen, K.; OKuivalainen, O.; Kylaheiko, K. (2004). Dynamic knowledge-related learning processes in internationalizing high-tech SMEs. International Journal of Production Economics, Vol. 89 No. 3, p. 363-378 https://ideas.repec.org/a/eee/proeco/v89y2004i3p363-378.html

Schaubroeck, J.; Lam, S. S. K.; Cha, S. E. (2007). Embracing transformational leadership: Team values and the impact of leader behavior on team performance. Journal of Applied Psychology, Vol. 92, No.4, pp. 1020-1030 https://doi.org/10.1037/0021-9010.92.4.1020 
INSIGHTS INTO REGIONAL DEVELOPMENT

ISSN 2669-0195 (online) http://jssidoi.org/jesi/

2021 Volume 3 Number 1 (March)

http://doi.org/10.9770/IRD.2021.3.1(3)

Make your research more visible, join the Twitter account of INSIGHTS INTO REGIONAL DEVELOPMENT:

@IntoInsights

Sternberg, R. (2000). Innovation networks and regional development-evidence from the European regional innovation survey (ERIS): Theoretical concepts, methodological approach, empirical basis. European Planning Studies Vol. 8, No. 4, pp. 389-407 https://doi.org/10.1080/713666420

Šūmakaris, P.; Korsakienè, R. (2017). Internationalization driving and hindering factors: the patterns traced in the case of small and medium-sized enterprises. Theoretical and practical aspects of economics and intellectual property: proceedings of scientific works. Mariupol: Priazovskyi State Technical University. No. 15, pp. 49-53. ISSN 2225-6407.

Szopik-Depczyńska, K. (2015) Effects of innovation activity in industrial enterprises in Eastern Poland. Oeconomia Copernicana. Vol. 6, No. 2, pp. 53-65. https://doi.org/10.12775/OeC.2015.012

Thayer, A. L.; Petruzzelli, A.; McClurg, C. E. (2018). Addressing the paradox of the team innovation process: A review and practical considerations. American Psychologist, Vol. 73, No. 4, pp. 363-375 https://doi.org/10.1037/amp0000310

Tjosvold, D.; Tang, M. M. L.; West, M. (2004). Reflexivity for team innovation in china - the contribution of goal interdependence. Group \& Organization Management, Vol. 29, No.,5, pp. 540-559 https://doi.org/10.1177/1059601103254911

Van Knippenberg, D. (2017). Team innovation. Annual Review of Organizational Psychology and Organizational Behavior, Vol. 4, pp. 211-233. http://dx.doi.org/10.1146/annurev-orgpsych-032516-113240

Van Knippenberg, D.; Schippers, M. C. (2007). Work group diversity. Annual Review of Psychology, Vol. 58, pp. 515-541. https://doi.org/10.1146/annurev.psych.58.110405.085546

Vissak, T.; Francioni, B. (2013). Serial nonlinear internationalization in practice: A case study. International Business Review, Vol. 22, No. 6, pp. 951-962. http://doi.org/10.1016/j.ibusrev.2013.01.010

Von Schomberg, L.; Blok, V. (2018). The turbulent age of innovation. Synthese https://doi.org/10.1007/s11229-018-01950-8

Voss, G. B.; Voss, Z. G. (2013). Strategic ambidexterity in small and medium-sized enterprises: Implementing exploration and exploitation in product and market domains. Organization Science, Vol. 24 No. 5, pp. 1459-1477 https://www.jstor.org/stable/42002915

Wang, J.; Tsai, K. (2003). Productivity Growth and R\&D Expenditure in Taiwan's Manufacturing Firms, NBER Working Paper 9724, National Bureau of Economic Research. http://www.nber.org/papers/w9724

Webber, S. S.; Donahue, L. M. (2001). Impact of highly and less job-related diversity on work group cohesion and performance: A metaanalysis. Journal of Management, Vol. 27, No. 2, pp. 141-162 https://doi.org/10.1177/014920630102700202

Welch, R.M.D.; Welch, L. (1997). Language: The forgotten factor in multinational management. European Management Journal, Vol. 15 No. 5, pp. 591-598. http://doi.org/10.1016/S0263-2373(97)00038-836

100. West, J.; \& Bogers, M. (2013). Leveraging external sources of innovation: A review of research on open innovation. Journal of Product Innovation Management, Vol. 31 No. 4, pp. 814-831 https://doi.org/10.1111/jpim.12125

101. West, M. A. (1990). The social psychology of innovation in groups. In M. A. West \& J. L. Farr (Eds.), Innovation and creativity at work: Psychological and organizational strategies (pp. 309 -333). Chichester, United Kingdom: Wiley. http://www.research.lancs.ac.uk/portal/en/publications/the-social-psychology-of-innovation-in-groups(5c27afc8-9868-49d4-963247a38c36d814)/export.html

102. West, M. A. (2002). Sparkling fountains or stagnant ponds: An integrative model of creativity and innovation implementation in work groups. Applied Psychology - An International Review - Psychologie Appliquee - Revue Internationale, Vol. 51 No. 3, pp. $355-387$ https://doi.org/10.1111/1464-0597.0095

103. Zedtwitz, M.; Gassmann, O. (2002). Market versus Technology Drive in R\&D Internationalization: Four Different Patterns of Managing Research and Development. Research Policy, Vol. 31, No. 4, pp. 569-588. http://www.sciencedirect.com/science/article/pii/S0048-7333(01)00125-1 
INSIGHTS INTO REGIONAL DEVELOPMENT

ISSN 2669-0195 (online) http://jssidoi.org/jesi/

2021 Volume 3 Number 1 (March)

http://doi.org/10.9770/IRD.2021.3.1(3)

Make your research more visible, join the Twitter account of INSIGHTS INTO REGIONAL DEVELOPMENT:

@IntoInsights

104. Zucchella, A.; Kabbara, D. (2013), The role of partnerships in the internationalisation process of small knowledge intensive firms (SKIFS), Management International, Vol. 18, No. 1, pp. 104-116. https://www.erudit.org/en/journals/mi/1900-v1-n1$\underline{\text { mi01139/1022223ar/abstract/ }}$

\section{Annexes}

Table 1. Level of Internationalization vs. Importance of Internationalization for Team Creativity

\begin{tabular}{|c|c|c|c|c|c|c|c|}
\hline & & $\begin{array}{l}\text { 14. Different } \\
\text { Nationalities }\end{array}$ & $\begin{array}{l}14 . \\
\text { Different } \\
\text { Languages }\end{array}$ & $\begin{array}{l}14 . \\
\text { International } \\
\text { Education } \\
\text { Backgrounds }\end{array}$ & $\begin{array}{l}14 . \\
\text { International } \\
\text { Working } \\
\text { Experience } \\
\text { Abroad }\end{array}$ & $\begin{array}{l}\text { 14. Working } \\
\text { with } \\
\text { International } \\
\text { Partners }\end{array}$ & $\begin{array}{l}\text { 14. Working } \\
\text { with } \\
\text { International } \\
\text { Clients }\end{array}$ \\
\hline \multirow[t]{2}{*}{$\begin{array}{l}11 . \\
\text { Nationalities }\end{array}$} & $\begin{array}{l}\text { Pearson } \\
\text { Correlation }\end{array}$ & $.207^{*}$ & $.214^{*}$ & .126 & .175 & .156 & .166 \\
\hline & Sig. (2-tailed) & .030 & .025 & .188 & .068 & .104 & .082 \\
\hline \multirow{2}{*}{ 11. Different Languages } & Sig. (2-tailed) & .216 & .013 & .158 & .090 & .229 & .189 \\
\hline & $\mathrm{N}$ & 110 & 110 & 110 & 110 & 110 & 110 \\
\hline $\begin{array}{l}11 . \quad \text { International } \\
\text { Education Backgrounds }\end{array}$ & $\begin{array}{l}\text { Pearson } \\
\text { Correlation }\end{array}$ & .174 & .147 & .121 & .161 & .181 & $.224^{*}$ \\
\hline \multirow{2}{*}{$\begin{array}{l}11 . \\
\text { Working } \\
\text { Abroad }\end{array}$} & Sig. (2-tailed) & .214 & .051 & .385 & .199 & .080 & .025 \\
\hline & $\mathrm{N}$ & 110 & 110 & 110 & 110 & 110 & 110 \\
\hline \multirow[t]{3}{*}{$\begin{array}{l}\text { 11. Working with } \\
\text { International Partners }\end{array}$} & $\begin{array}{l}\text { Pearson } \\
\text { Correlation }\end{array}$ & $.227^{*}$ & .181 & .100 & $.195^{*}$ & $.297^{* *}$ & $.288^{* *}$ \\
\hline & Sig. (2-tailed) & .017 & .059 & .301 & .041 & .002 & .002 \\
\hline & $\mathrm{N}$ & 110 & 110 & 110 & 110 & 110 & 110 \\
\hline \multirow[t]{3}{*}{$\begin{array}{l}\text { 11. Working with } \\
\text { International Clients }\end{array}$} & $\begin{array}{l}\text { Pearson } \\
\text { Correlation }\end{array}$ & .175 & $.240^{*}$ & .047 & .181 & $.231^{*}$ & $.249^{* *}$ \\
\hline & Sig. (2-tailed) & .067 & .011 & .627 & .058 & .015 & .009 \\
\hline & $\mathrm{N}$ & 110 & 110 & 110 & 110 & 110 & 110 \\
\hline
\end{tabular}

Source: Developed by the paper authors, based on the research results 
INSIGHTS INTO REGIONAL DEVELOPMENT

ISSN 2669-0195 (online) http://jssidoi.org/jesi/

2021 Volume 3 Number 1 (March)

http://doi.org/10.9770/IRD.2021.3.1(3)

Make your research more visible, join the Twitter account of INSIGHTS INTO REGIONAL DEVELOPMENT:

@ IntoInsights

Table 2. Level of Team Internationalization vs. Importance of Internationalization for Team Performance \& Efficiency

\begin{tabular}{|c|c|c|c|c|c|c|c|}
\hline & & $\begin{array}{l}\text { 15. Different } \\
\text { Nationalities }\end{array}$ & $\begin{array}{l}\text { 15. Different } \\
\text { Languages }\end{array}$ & $\begin{array}{l}15 . \\
\text { International } \\
\text { Education } \\
\text { Backgrounds }\end{array}$ & $\begin{array}{l}15 . \\
\text { International } \\
\text { Working } \\
\text { Experience } \\
\text { Abroad }\end{array}$ & $\begin{array}{l}\text { 15. Working } \\
\text { with } \\
\text { International } \\
\text { Partners }\end{array}$ & $\begin{array}{l}\text { 15. Working } \\
\text { with } \\
\text { International } \\
\text { Clients }\end{array}$ \\
\hline \multirow[t]{3}{*}{$\begin{array}{l}\text { 11. Different } \\
\text { Nationalities }\end{array}$} & Pearson Correlation & $.310^{* *}$ & $.271^{* *}$ & $.288^{* *}$ & $.219^{*}$ & .106 & .091 \\
\hline & Sig. (2-tailed) & .001 & .004 & .002 & .021 & .271 & .346 \\
\hline & $\mathrm{N}$ & 110 & 110 & 110 & 110 & 110 & 110 \\
\hline \multirow{3}{*}{$\begin{array}{ll}11 . & \text { Different } \\
\text { Languages } & \end{array}$} & Pearson Correlation & $.328^{* *}$ & $.411^{* *}$ & $.320^{* *}$ & $.239^{*}$ & .186 & .173 \\
\hline & Sig. (2-tailed) & .000 & .000 & .001 & .012 & .051 & .070 \\
\hline & $\mathrm{N}$ & 110 & 110 & 110 & 110 & 110 & 110 \\
\hline \multirow{3}{*}{$\begin{array}{l}11 . \quad \text { International } \\
\text { Education } \\
\text { Backgrounds }\end{array}$} & Pearson Correlation & $.221^{*}$ & .138 & $.266^{* *}$ & $.232^{*}$ & .150 & .187 \\
\hline & Sig. (2-tailed) & .021 & .151 & .005 & .015 & .118 & .050 \\
\hline & $\mathrm{N}$ & 110 & 110 & 110 & 110 & 110 & 110 \\
\hline \multirow{3}{*}{$\begin{array}{l}11 . \quad \text { International } \\
\text { Working Experience } \\
\text { Abroad }\end{array}$} & Pearson Correlation & .088 & .160 & .098 & .178 & .102 & .138 \\
\hline & Sig. (2-tailed) & .360 & .095 & .307 & .063 & .288 & .151 \\
\hline & $\mathrm{N}$ & 110 & 110 & 110 & 110 & 110 & 110 \\
\hline \multirow{3}{*}{$\begin{array}{l}\text { 11. Working with } \\
\text { International Partners }\end{array}$} & Pearson Correlation & $.232^{*}$ & $.307^{* * *}$ & $.227^{*}$ & $.223^{*}$ & $.416^{* *}$ & $.460^{* *}$ \\
\hline & Sig. (2-tailed) & .015 & .001 & .017 & .019 & .000 & .000 \\
\hline & $\mathrm{N}$ & 110 & 110 & 110 & 110 & 110 & 110 \\
\hline \multirow{3}{*}{$\begin{array}{l}\text { 11. Working with } \\
\text { International Clients }\end{array}$} & Pearson Correlation & .168 & $.287^{* *}$ & $.198^{*}$ & $.253^{\text {** }}$ & $.405^{* *}$ & $.455^{* *}$ \\
\hline & Sig. (2-tailed) & .079 & .002 & .038 & .008 & .000 & .000 \\
\hline & $\mathrm{N}$ & 110 & 110 & 110 & 110 & 110 & 110 \\
\hline
\end{tabular}

Source: Developed by the paper authors, based on the research results 
INSIGHTS INTO REGIONAL DEVELOPMENT

ISSN 2669-0195 (online) http://jssidoi.org/jesi/

2021 Volume 3 Number 1 (March)

http://doi.org/10.9770/IRD.2021.3.1(3)

Make your research more visible, join the Twitter account of INSIGHTS INTO REGIONAL DEVELOPMENT:

@ IntoInsights

Table 3. Importance of Internationalization for Team Creativity vs. Importance of Internationalization for Team Performance \& Efficiency

\begin{tabular}{|c|c|c|c|c|c|c|c|}
\hline & & $\begin{array}{l}\text { 15. Different } \\
\text { Nationalities }\end{array}$ & $\begin{array}{l}\text { 15. Different } \\
\text { Languages }\end{array}$ & $\begin{array}{l}15 . \\
\text { International } \\
\text { Education } \\
\text { Backgrounds }\end{array}$ & $\begin{array}{l}15 . \\
\text { International } \\
\text { Working } \\
\text { Experience } \\
\text { Abroad } \\
\end{array}$ & $\begin{array}{l}\text { 15. Working } \\
\text { with } \\
\text { International } \\
\text { Partners } \\
\end{array}$ & $\begin{array}{l}\text { 15. Working } \\
\text { with } \\
\text { International } \\
\text { Clients }\end{array}$ \\
\hline \multirow[t]{3}{*}{$\begin{array}{l}14 . \\
\text { Nationalities }\end{array}$} & $\begin{array}{l}\text { Pearson } \\
\text { Correlation }\end{array}$ & $.490^{* * *}$ & $.418^{* * *}$ & $.442^{* * *}$ & $.506^{* *}$ & $.500^{* *}$ & $.548^{* *}$ \\
\hline & Sig. (2-tailed) & .000 & .000 & .000 & .000 & .000 & .000 \\
\hline & $\mathrm{N}$ & 110 & 110 & 110 & 110 & 110 & 110 \\
\hline \multirow[t]{3}{*}{$\begin{array}{l}14 . \\
\text { Languages }\end{array}$} & $\begin{array}{l}\text { Pearson } \\
\text { Correlation }\end{array}$ & $.527^{* * *}$ & $.651^{* *}$ & $.430^{* *}$ & $.423^{* *}$ & $.321^{* * *}$ & $.411^{* *}$ \\
\hline & Sig. (2-tailed) & .000 & .000 & .000 & .000 & .001 & .000 \\
\hline & $\mathrm{N}$ & 110 & 110 & 110 & 110 & 110 & 110 \\
\hline \multirow{3}{*}{$\begin{array}{l}14 . \quad \text { International } \\
\text { Education } \\
\text { Backgrounds }\end{array}$} & $\begin{array}{l}\text { Pearson } \\
\text { Correlation }\end{array}$ & $.464^{* *}$ & $.404^{* * *}$ & $.574^{* *}$ & $.588^{* * *}$ & $.559^{* *}$ & $.522^{* *}$ \\
\hline & Sig. (2-tailed) & .000 & .000 & .000 & .000 & .000 & .000 \\
\hline & $\mathrm{N}$ & 110 & 110 & 110 & 110 & 110 & 110 \\
\hline \multirow{3}{*}{$\begin{array}{l}14 . \\
\text { Working } \\
\text { Abroad }\end{array}$} & $\begin{array}{l}\text { Pearson } \\
\text { Correlation }\end{array}$ & $.535^{* *}$ & $.433^{* *}$ & $.524^{* *}$ & $.683^{* * *}$ & $.643^{* *}$ & $.656^{* *}$ \\
\hline & Sig. (2-tailed) & .000 & .000 & .000 & .000 & .000 & .000 \\
\hline & $\mathrm{N}$ & 110 & 110 & 110 & 110 & 110 & 110 \\
\hline \multirow[t]{3}{*}{$\begin{array}{l}\text { 14. Working with } \\
\text { International Partners }\end{array}$} & $\begin{array}{l}\text { Pearson } \\
\text { Correlation }\end{array}$ & $.406^{* *}$ & $.372^{* *}$ & $.380^{* *}$ & $.538^{* *}$ & $.728^{* * *}$ & $.713^{* *}$ \\
\hline & Sig. (2-tailed) & .000 & .000 & .000 & .000 & .000 & .000 \\
\hline & $\mathrm{N}$ & 110 & 110 & 110 & 110 & 110 & 110 \\
\hline \multirow[t]{3}{*}{$\begin{array}{l}\text { 14. Working with } \\
\text { International Clients }\end{array}$} & $\begin{array}{l}\text { Pearson } \\
\text { Correlation }\end{array}$ & $.443^{* *}$ & $.387^{* *}$ & $.397^{* * *}$ & $.564^{* *}$ & $.720^{* *}$ & $.735^{* *}$ \\
\hline & Sig. (2-tailed) & .000 & .000 & .000 & .000 & .000 & .000 \\
\hline & $\mathrm{N}$ & 110 & 110 & 110 & 110 & 110 & 110 \\
\hline
\end{tabular}

Source: Developed by the paper authors, based on the research results 
INSIGHTS INTO REGIONAL DEVELOPMENT

ISSN 2669-0195 (online) http://jssidoi.org/jesi/

2021 Volume 3 Number 1 (March)

http://doi.org/10.9770/IRD.2021.3.1(3)

Make your research more visible, join the Twitter account of INSIGHTS INTO REGIONAL DEVELOPMENT:

@IntoInsights

Dr. Mindaugas LAUŽIKAS is a Professor at Vilnius University Business School, Doctor of Economic Sciences, Director of GILE Experts (Malta). Lecturing experience in countries, such as Georgia, Sweden, France, Spain, Italy, Malta, Moldova, South Korea and Lithuania, is supported by publications in the field of knowledge economy, entrepreneurship and innovation. Research interests: national systems of innovation, entrepreneurship, knowledge and innovation management, innovation and human resource strategies, business intelligence.

ORCID ID: $\underline{\text { http://orcid.org/0000-0002-6113-7794 }}$

Aistė MILIŪTÉ is a teacher/researcher at Vilnius University Business School and entrepreneur within the mineral water and healthcare industries, a founder of AKVAVITA company.

ORCID ID: http://orcid.org/0000-0002-9667-3730

Mukhammad KHALILI

ORCID ID: http://orcid.org/0000-0003-2104-0696

Copyright (C) 2021 by author(s) and VsI Entrepreneurship and Sustainability Center

This work is licensed under the Creative Commons Attribution International License (CC BY).

http://creativecommons.org/licenses/by/4.0/

(c) (†) Open Access 